\title{
CHROMOSOMAL POLYMORPHISM IN 12 POPULATIONS OF Mikania micrantha (COMPOSITAE)
}

\author{
Eliane M.D. Maffei ${ }^{1}$, M.A. Marin-Morales ${ }^{2}$, P.M. Ruas $^{1}$, C.F. Ruas ${ }^{1}$ and N.I. Matzenbacher ${ }^{3}$
}

\begin{abstract}
Mikania micrantha is a climbing perennial weed of the family Asteraceae, with a vast distribution from South America to south of the United States. This species is widely distributed throughout Brazil, where it shows little morphological variation. Mitotic chromosomes of 12 populations of $M$. micrantha derived from several Brazilian sites were studied using Feulgen staining and C-banding. The populations included eight diploid $(2 n=36$ and 42$)$ and four tetraploid $(2 n=72)$ cytotypes. Chromosome numbers of $2 n=36$ and $2 n=42$ are reported for the first time for $M$. micrantha. These populations had a secondary constriction in the middle of the larger arm of chromosome pair 1, following the same pattern described for all Mikania species analyzed so far. Numerical and structural variation of the chromosomes was quite common among the karyotypes and nearly all cytotypes differed from each other in some aspect. Most of the chromosomal differentiation may be attributed to inversions and addition or deletion of DNA fragments. C-banding, applied to three of the 12 populations, also revealed polymorphism in the distribution of heterochromatin. Additionally, one to 14 supernumerary or B-chromosomes were observed. The Bs were detected in six of the 12 populations and varied in size, number, and structure among karyotypes and also among cells of the same root meristem. The B chromosomes were also heterochromatic, showing a C-banding pattern similar to the A chromosomes, and suggesting that they may be derived from the chromosomes of the A complement.
\end{abstract}

\section{INTRODUCTION}

Mikania micrantha H.B.K. is a climbing perennial weed of the family Asteraceae distributed throughout tropical and subtropical regions of the American continent. It is a pioneer species, frequently found in disturbed environments or in changing communities where the original vegetation has been destroyed for crop introduction. It holds an advantage over many other pioneer species because of its vigorous vegetative and sexual reproduction (Swamy and Ramakrishnan, 1987). M. micrantha is of great ecological importance due to its participation in the reposition of degraded or newly open habitats. It is widespread throughout many Brazilian regions where it grows in environments such as forest borders, roadsides, along fences, and in newly changed habitats.

Numerous cytotypes have been reported in $M$. micrantha, including $n=19$ in a population from Colombia and $n=19$ and 20 in a West Indian population (Powell and King, 1969a,b). Chromosome numbers of $n=17$ and $n=19$ were reported for populations from Ecuador (King et al., 1976) and Argentina (Turner et al., 1979 and Waisman et al., 1984). Nineteen bivalents were found in one population of $M$. micrantha from Mexico (Strother, 1983) and another from Jamaica (Keil et al., 1988). The karyotype of a polyploid population $(2 n=72)$ from

${ }^{l}$ Departamento de Biologia Geral, CCB, Universidade Estadual de Londrina, 86051-990 Londrina, PR, Brasil. Send correspondence to P.M.R. ${ }^{2}$ Departamento de Biologia da Universidade Estadual Paulista, Assis, SP, Brasil.

${ }^{3}$ Departamento de Botânica, Universidade Federal do Rio Grande do Sul, Porto Alegre, RS, Brasil.
Londrina, Brazil, was analyzed by Ruas and Ruas (1987). The present study examines the karyotypes of 12 populations of M. micrantha collected from different Brazilian sites to help provide a better understanding of chromosome variation in this species.

\section{MATERIAL AND METHODS}

The specimens of M. micrantha were obtained from 12 sites in Brazil (Table I) and cultivated in a greenhouse. At least five samples were collected from each population. Root tips were collected from potted plants, pretreated with $0.002 \mathrm{M}$ 8-hydroxyquinoline for $4 \mathrm{~h}$ at $8^{\circ} \mathrm{C}$, fixed in 3:1 ethanol-glacial acetic acid overnight, transferred to $70 \%$ alcohol, and stored in a refrigerator until used. The conventional Feulgen method with modifications described by Nogueira et al. (1995) was used for chromosome preparations. C-banding was obtained with the method of Schwarzacher et al. (1980).

The morphological chromosome data used in this study included: 1) absolute length of individual chromosomes and haploid chromosome length, both measured in $\mu \mathrm{m} ; 2)$ relative length of each chromosome; 3) arm ratio for each chromosome (long arm/short arm).

The chromosomes were classified according to the nomenclature of Levan et al. (1964). Diploid numbers were determined by counting the chromosomes in at least 10 metaphases of every sample of each population. Supernumerary or B chromosomes were analyzed in 25 cells of each population. The average of the chromosome lengths for each chromosome pair was obtained from the measurements of five well-spread metaphases and was used for the analysis and for the construction of the idiograms. Karyotype asymmetry was determined by using the 
Table I - Sites of origin, collection number, chromosome number, and karyotypic formula of 12 populations of Mikania micrantha.

\begin{tabular}{|c|c|c|c|}
\hline Collection sites $^{\mathrm{a}}$ & $\begin{array}{l}\text { Voucher } \\
\text { specimens }\end{array}$ & $\begin{array}{c}\text { Chromosome } \\
\text { number }\end{array}$ & $\begin{array}{l}\text { Karyotypic } \\
\text { formula }\end{array}$ \\
\hline Alfredo Guedes, SP, $22^{\circ} 35^{\prime} \mathrm{S}, 48^{\circ} 42^{\prime} \mathrm{W}$ & FUEL -11446 & 36 & $26 m+10 s m$ \\
\hline Apucarana, PR, $23^{\circ} 33^{\prime} \mathrm{S}, 51^{\circ} 27^{\prime} \mathrm{W}$ & FUEL-11017 & $72+0-2 \mathrm{Bs}$ & $40 m+30 s m+2 s t$ \\
\hline Campinas, SP, $22^{\circ} 54^{\prime} \mathrm{S}, 47^{\circ} 03^{\prime} \mathrm{W}$ & FUEL-09331 & $36+6-7 \mathrm{Bs}$ & $26 \mathrm{~m}+10 \mathrm{sm}$ \\
\hline Estrela do Norte, SP, $22^{\circ} 29^{\prime} \mathrm{S}, 51^{\circ} 39^{\prime} \mathrm{W}$ & FUEL-11447 & $36+0-1 \mathrm{Bs}$ & $22 m+14 s m$ \\
\hline 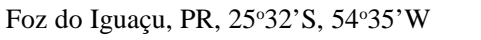 & FUEL-17307 & 72 & $40 m+26 s m+6 s t$ \\
\hline 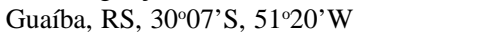 & $\mathrm{ICN}^{\mathrm{c}}-44499$ & 72 & $40 m+32 s m$ \\
\hline Joinville, SC, $26^{\circ} 18^{\prime} \mathrm{S}, 48^{\circ} 50^{\prime} \mathrm{W}$ & FUEL-14725 & 42 & $26 m+14 s m+2 s t$ \\
\hline 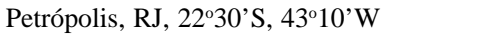 & $\mathrm{UEC}^{\mathrm{d}}-26183$ & 36 & $22 m+12 s m+2 s t$ \\
\hline Piracicaba, SP, $22^{\circ} 17^{\prime} \mathrm{S}, 42^{\circ} 32^{\prime} \mathrm{W}$ & FUEL-09335 & $36+4-14 \mathrm{Bs}$ & $20 m+16 s m$ \\
\hline Praia Grande, SP, $24^{\circ} 00^{\prime} S, 46^{\circ} 24^{\prime} \mathrm{W}$ & FUEL-09334 & $36+0-7 \mathrm{Bs}$ & $26 m+10 s m$ \\
\hline Praia de Ipanema, PR, $25^{\circ} 49^{\prime} \mathrm{S}, 48^{\circ} 32^{\prime} \mathrm{W}$ & FUEL-17306 & 36 & $24 m+12 s m$ \\
\hline 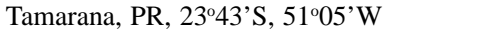 & FUEL-11448 & $72+0-2 \mathrm{Bs}$ & $46 m+24 s m+2 s t$ \\
\hline
\end{tabular}

a The abbreviations correspond to Brazilian states. SP = São Paulo, PR = Paraná, RS = Rio Grande do Sul, RJ = Rio de Janeiro. ${ }^{\mathrm{b}} \mathrm{FUEL}=$ Herbário do Departamento de Biologia Animal e Vegetal, Universidade Estadual de Londrina, Londrina, PR, Brazil. 'ICN = Herbário do Departamento de Botânica da Universidade Federal do Rio Grande do Sul, RS, Brazil. 'UEC = Herbário do Departamento de Botânica da Universidade Estadual de Campinas, Campinas, SP, Brazil. Bs, B cromosomes; m, metacentric; sm, submetacentric; st, subtelocentric.

index total form percent (TF\%) according to Huziwara (1962). The asymmetry index was also analyzed by using a plot of the values generated by the Zarco index (Zarco, 1986). The TF\%, the size of the largest and smallest chromosomes, the haploid chromosome length and relative length, and the arm ratio values were compared by oneway analysis of variance and Tukey's test (Steel and Torrie, 1960).

\section{RESULTS AND DISCUSSION}

\section{Karyotype characterization}

The cytotypes of $M$. micrantha derived from 12 collection sites were studied (Table I). Their karyotypes and respective idiograms are in Figures 1-4. Eight cytotypes were diploid, seven with $2 n=2 x=36$ and one with $2 n=$ $2 x=42$ chromosomes; four were tetraploid with $2 n=4 x=$ 72 . Numbers of $2 n=36$ and $2 n=42$ are documented here for the first time. Comparisons among the diploid cytotypes $(2 n=36)$ showed that whereas the karyotypes followed similar patterns, minor structural differences were detected in almost all corresponding chromosomes (Table II; Figures 1 and 3). Pair 1 was the most inconstant, showing variation in both size and structure. The largest chromosomes were in cytotypes from Estrela do Norte and Praia de Ipanema, with haploid sets of $32.5 \pm 1.62 \mu \mathrm{m}$ and 31.3 $\pm 0.36 \mu \mathrm{m}$, respectively (Table II; Figure 1E,F). The population from Praia Grande, on the other hand, exhibited the smallest chromosomes and a haploid set of $19.9 \pm 1.55$ $\mu \mathrm{m}$ (Figures 1C and 3C). The differences in chromosome sizes encompass almost all chromosome pairs, reflecting a gain of genetic material that may have derived through mechanisms of DNA amplification. Two other diploid cytotypes (populations from Alfredo Guedes and Campinas) with $2 n=36$ showed the same karyotype formula and similar haploid sets (Figures 1D,G and 3D,G; Tables I, II), but they differed slightly in the arm-ratio values, which were probably modified by inversions. Similar conclusions can be reached in the analysis of the four tetraploid cytotypes with $2 n=4 x=72$ chromosomes (Tables III, IV; Figures 2 and 3). In this group, only the population from Apucarana (PR) differed in the value of the haploid chromosome length (Table III). Most of the variation among the tetraploids was represented by centromeric shifts (Table V) even though the general karyotype pattern, described for the genus (Ruas and Ruas, 1987; Ruas and AguiarPerecin, 1997), was maintained.

The longest chromosome in the karyotypes of all populations of $M$. micrantha studied had a secondary constriction located in the middle of the long arm (Figures 1$3)$. This is a conservative pattern which has been described in many Mikania species. Ruas and Ruas (1987) studied six species of Mikania and suggested that the secondary constriction might be considered a cytological marker for the genus, which could help in the identification of the species. Those results were fully supported by the work of Ruas and Aguiar-Perecin (1997), in which the same karyotype pattern was revealed in 10 other Mikania species.

Karyotype asymmetry was also determined for all cytotypes. The TF\% and Zarco index (Tables II, III; Figure 4) showed that the population from Campinas had the karyotype with the highest degree of symmetry, whereas the karyotypes of the populations from Praia de Ipanema, Joinville, and Petrópolis were the most asymmetrical. The highest value of interchromosomal asymmetry (Tables II, III) was found in the population from Estrela do Norte. This value reflects the huge size of chromosome 1 , which may have resulted from duplication of parts of this chromosome pair. Less significant differences in the Zarco in- 
$1 \mathbf{a}$

\section{A}

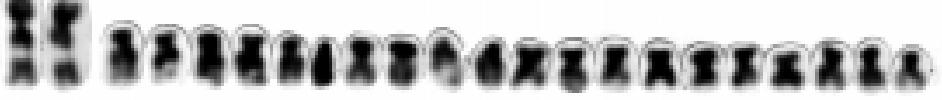

REREartanabos

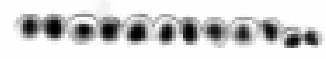

B

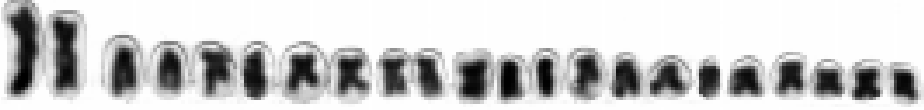

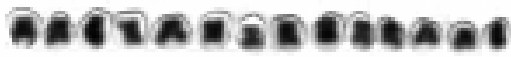

C

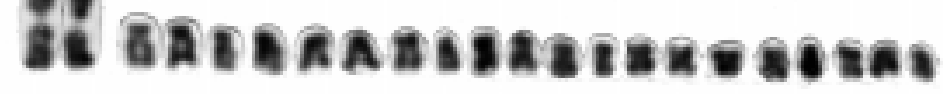

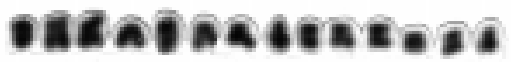

D

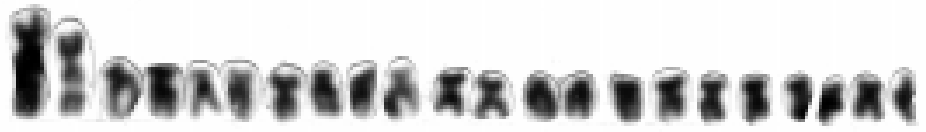

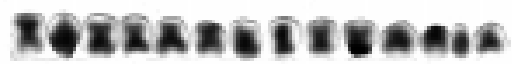

E

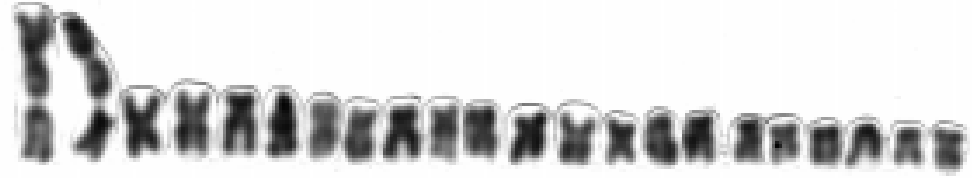

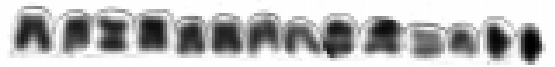

$1 \mathbf{b}$

$\mathbf{F}$

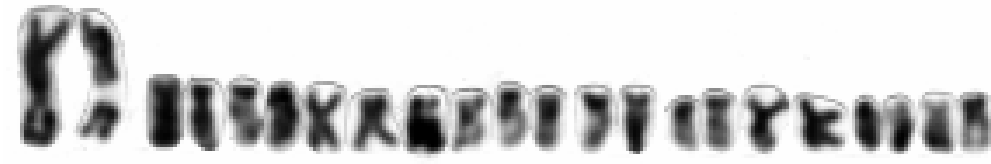

RRA

\section{G}

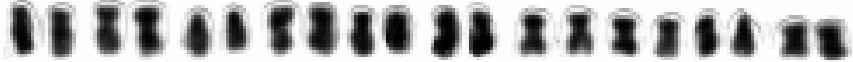

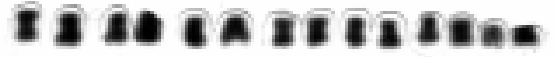
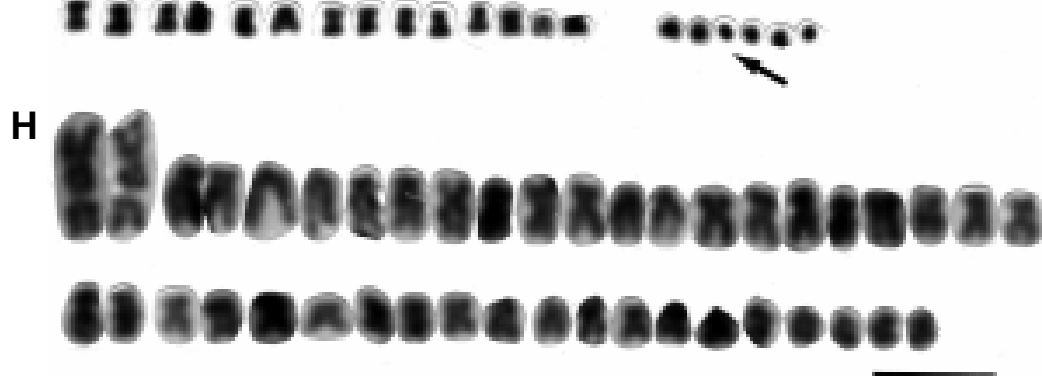

Figure 1 - a, Karyotypes of diploid cytotypes of Mikania micrantha. A. Piracicaba, B. Petrópolis, C. Praia Grande, D. Alfredo Guedes, E. Estrela do Norte. $\mathrm{Bar}=4 \mu \mathrm{m}$. Arrows indicate B-chromosomes. b, Karyotypes of three diploid cytotypes of Mikania micrantha. F. Praia de Ipanema, G. Campinas (with $2 n$ $=36$ chromosomes), $\mathbf{H}$. Joinville (with $2 n=42$ chromosomes). Bar $=4 \mu \mathrm{m}$. Arrow indicates B-chromosomes. 
A

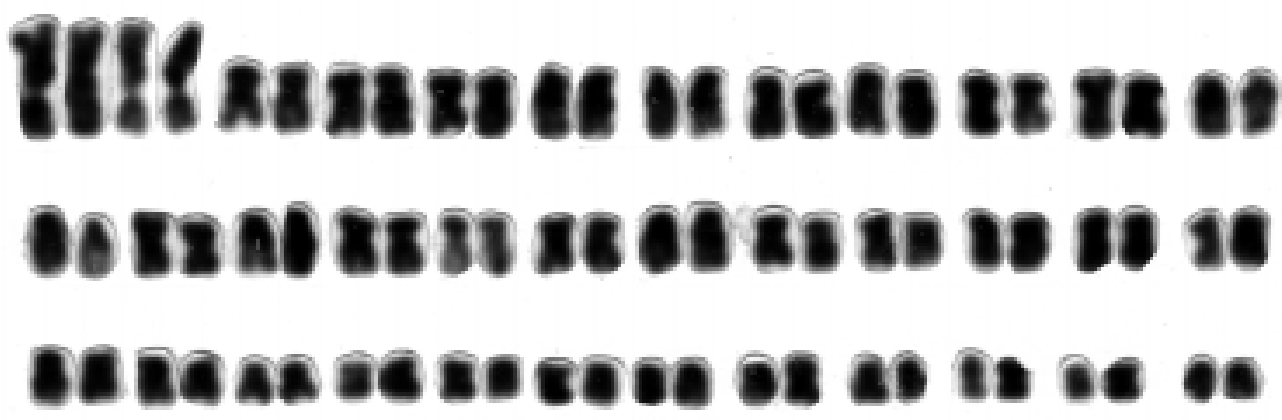

B

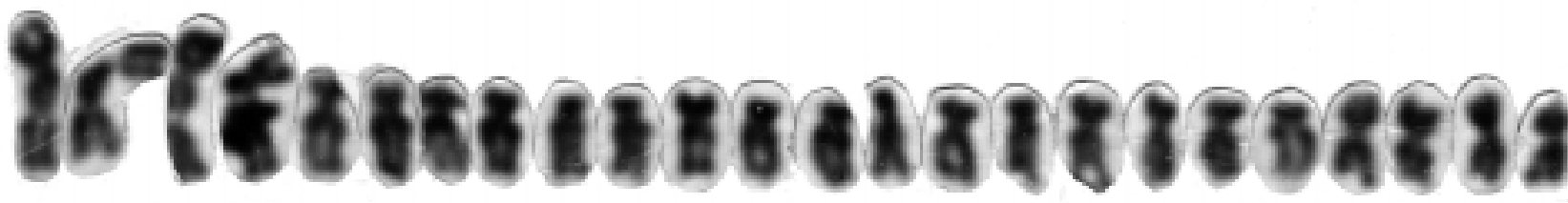
2ล883

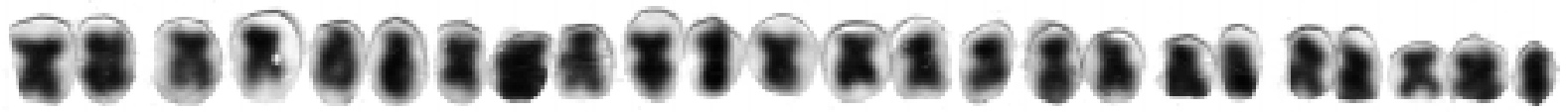

C

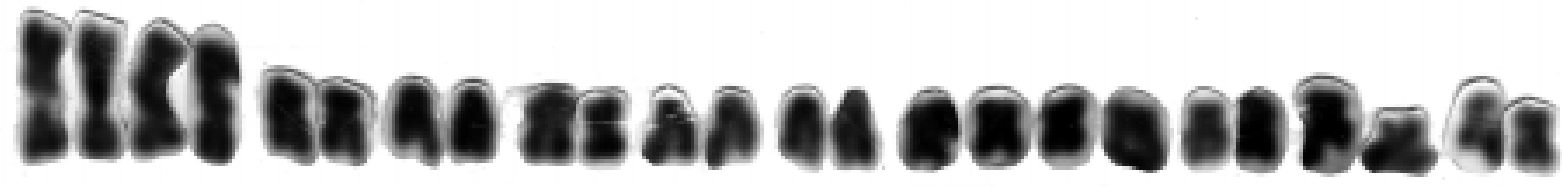

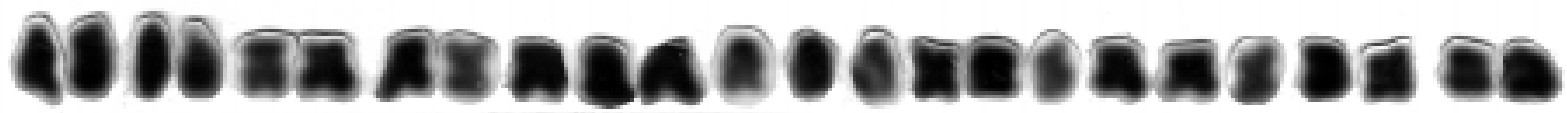

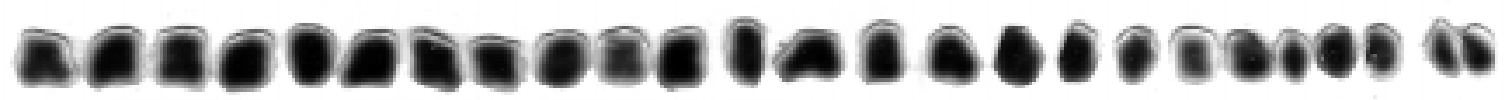

D

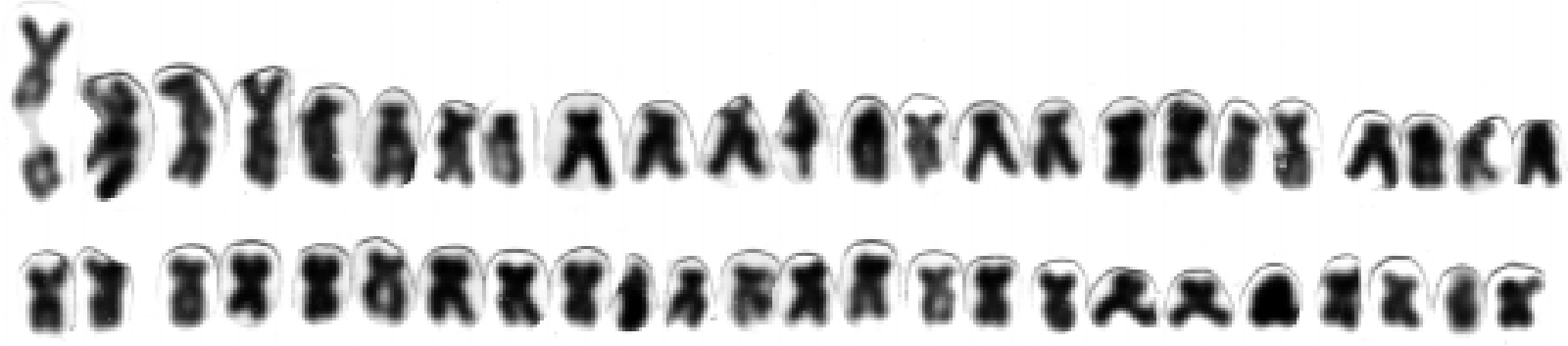

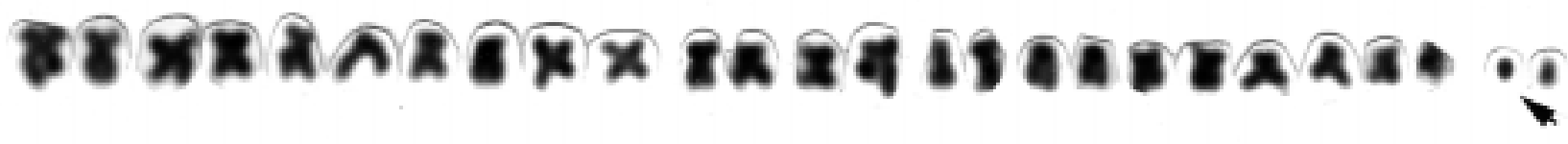

Figure 2 - Karyotypes of four tetraploid cytotypes of Mikania micrantha including the populations from: A. Foz do Iguaçu, B. Guaíba, C. Tamarana, D. Apucarana. Bar $=4 \mu \mathrm{m}$. Arrowhead indicates B-chromosomes. 
A

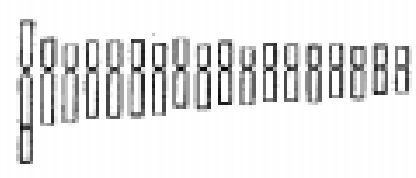

B

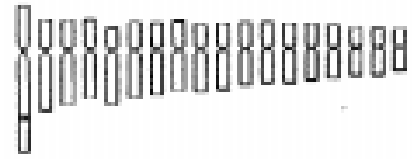

C

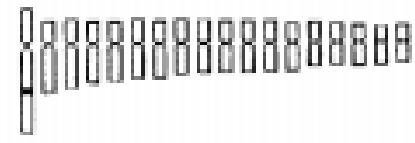

D

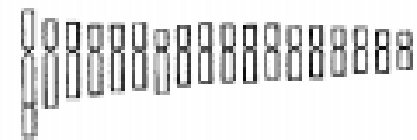

E

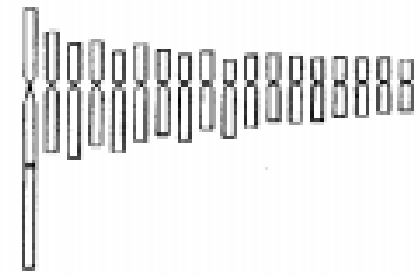

F

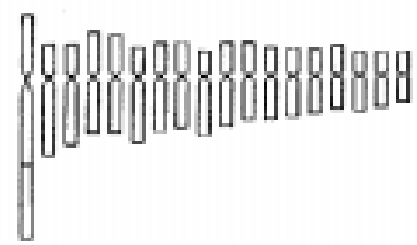

$\mathbf{G}$

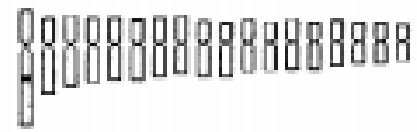

H

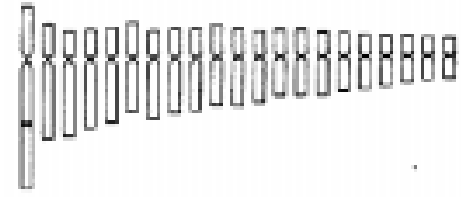

I

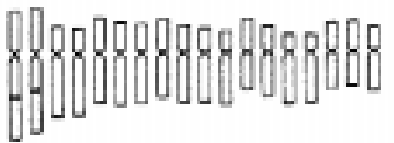

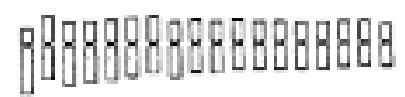

$\mathbf{J}$

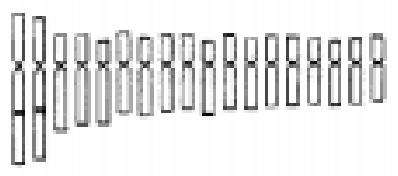

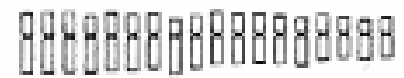

$\mathrm{K}$

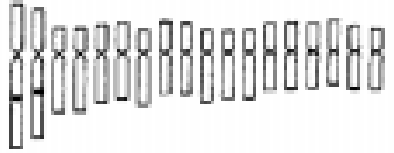

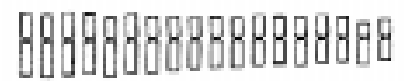

L
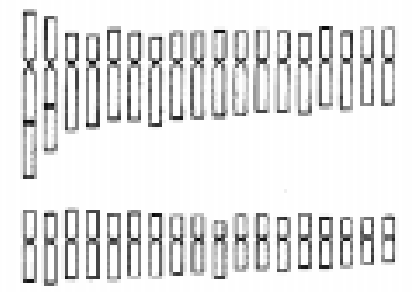

Figure 3 - Comparative idiograms of 12 cytotypes of Mikania micrantha. A. Piracicaba, B. Petrópolis, C. Praia Grande, D. Alfredo Guedes, E. Estrela do Norte, F. Praia de Ipanema, G. Campinas, H. Joinville, I. Foz do Iguaçu, J. Guaíba, K. Tamarana, L. Apucarana. Bar $=4 \mu \mathrm{m}$. The B-chromosomes are not represented.

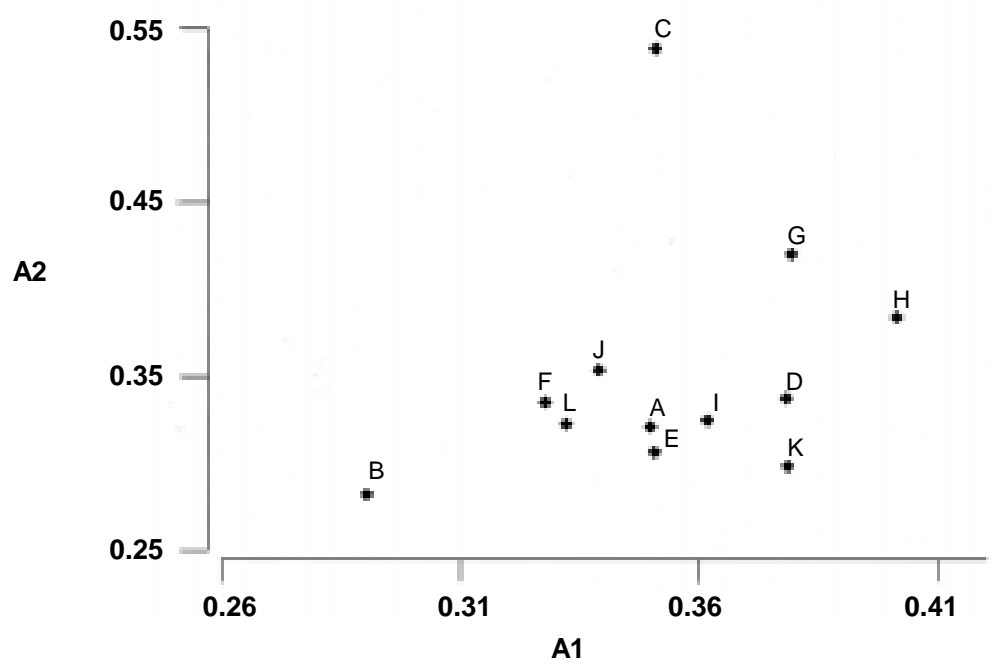

Figure 4 - Diagram projection of the mean intrachromosomal asymmetry index (A1) against the mean interchromosomal asymmetry index (A2) of 12 populations of Mikania micrantha . A = Alfredo Guedes, $\mathbf{B}=$ Campinas, $\mathbf{C}=$ Estrela do Norte, $\mathbf{D}=$ Petrópolis, $\mathbf{E}=$ Piracicaba, $\mathbf{F}=$ Praia Grande, $\mathbf{G}=$ Praia de Ipanema, $\mathbf{H}=$ Joinville, $\mathbf{I}=$ Apucarana, $\mathbf{J}=$ Foz do Iguaçu, $\mathbf{K}=$ Guaíba, $\mathbf{L}=$ Tamarana. 
Table II - Chromosome length $(\mu \mathrm{m})$, haploid chromosome length (HCL), ratio of longest/shortest chromosomes (L/S), and karyotype symmetry using total form (TF\%) and Zarco index of cytotypes of Mikania micrantha, seven with $2 n=36$, and one with $2 n=42$. $^{\text {a }}$

\begin{tabular}{|lccccccc|}
\hline Population & \multicolumn{2}{c}{$\begin{array}{c}\text { Chromosome length } \\
\text { (largest-smallest }-\mu \mathrm{m})\end{array}$} & HCL & L/S & TF\% & Zarco index \\
\cline { 3 - 7 } & & & & & A1 & A2 \\
\hline Alfredo Guedes & $2.5 \pm 0.27^{\mathrm{d}}$ & $0.7 \pm 0.04^{\mathrm{b}}$ & $21.8 \pm 1.90^{\mathrm{cde}}$ & $3.4 \pm 0.32^{\mathrm{c}}$ & $37.7 \pm 1.06^{\mathrm{bc}}$ & 0.35 & 0.32 \\
Campinas & $2.3 \pm 0.28^{\mathrm{d}}$ & $0.7 \pm 0.04^{\mathrm{b}}$ & $20.8 \pm 0.78^{\mathrm{de}}$ & $3.2 \pm 0.49^{\mathrm{c}}$ & $39.8 \pm 0.26^{\mathrm{b}}$ & 0.29 & 0.28 \\
Estrela do Norte & $5.2 \pm 0.39^{\mathrm{b}}$ & $1.0 \pm 0.05^{\mathrm{b}}$ & $32.5 \pm 1.62^{\mathrm{b}}$ & $5.0 \pm 0.46^{\mathrm{b}}$ & $37.5 \pm 0.96^{\mathrm{bc}}$ & 0.35 & 0.54 \\
Petrópolis & $2.9 \pm 0.15^{\mathrm{d}}$ & $0.9 \pm 0.05^{\mathrm{b}}$ & $25.0 \pm 1.83^{\mathrm{c}}$ & $3.3 \pm 0.08^{\mathrm{c}}$ & $36.4 \pm 0.14^{\mathrm{c}}$ & 0.38 & 0.34 \\
Piracicaba & $2.7 \pm 0.36^{\mathrm{d}}$ & $0.9 \pm 0.13^{\mathrm{b}}$ & $23.6 \pm 2.44^{\mathrm{cd}}$ & $3.2 \pm 0.38^{\mathrm{c}}$ & $38.3 \pm 1.02^{\mathrm{bc}}$ & 0.35 & 0.31 \\
Praia Grande & $2.4 \pm 0.18^{\mathrm{d}}$ & $0.7 \pm 0.09^{\mathrm{b}}$ & $19.9 \pm 1.55^{\mathrm{e}}$ & $3.5 \pm 0.34^{\mathrm{c}}$ & $38.3 \pm 0.47^{\mathrm{bc}}$ & 0.33 & 0.34 \\
Praia de Ipanema & $4.4 \pm 0.47^{\mathrm{c}}$ & $1.0 \pm 0.03^{\mathrm{b}}$ & $31.3 \pm 0.36^{\mathrm{b}}$ & $4.5 \pm 0.63^{\mathrm{b}}$ & $36.1 \pm 0.36^{\mathrm{c}}$ & 0.38 & 0.42 \\
Joinville & $3.5 \pm 0.20^{\mathrm{d}}$ & $0.8 \pm 0.06^{\mathrm{b}}$ & $32.2 \pm 1.13^{\mathrm{b}}$ & $4.4 \pm 0.28^{\mathrm{b}}$ & $35.2 \pm 0.42^{\mathrm{c}}$ & 0.40 & 0.39 \\
\hline
\end{tabular}

${ }^{a}$ Means within each column followed by different lowercase letters are significantly different at the 5\% level by the Tukey test.

Table III - Chromosome length $(\mu \mathrm{m})$, haploid chromosome length (HCL), ratio of longest/shortest chromosomes (L/S), and karyotype symmetry using total form (TF\%) and Zarco index of four tetraploid cytotypes of Mikania micrantha with $2 n=72$ chromosomes. $^{\text {a }}$

\begin{tabular}{|c|c|c|c|c|c|c|c|}
\hline \multirow[t]{2}{*}{ Population } & \multirow{2}{*}{\multicolumn{2}{|c|}{$\begin{array}{l}\text { Chromosome length } \\
\text { (largest-smallest }-\mu \mathrm{m})\end{array}$}} & \multirow[t]{2}{*}{ HCL } & \multirow[t]{2}{*}{$\mathrm{L} / \mathrm{S}$} & \multirow[t]{2}{*}{$\mathrm{TF} \%$} & \multicolumn{2}{|c|}{ Zarco index } \\
\hline & & & & & & $\mathrm{A} 1$ & A2 \\
\hline Apucarana & $3.2 \pm 0.25^{\mathrm{b}}$ & $0.6 \pm 0.32^{\mathrm{b}}$ & $52.2 \pm 4.10^{\mathrm{b}}$ & $3.9 \pm 0.49^{b}$ & $37.3 \pm 1.15^{\mathrm{b}}$ & 0.36 & 0.32 \\
\hline Foz do Iguaçu & $2.6 \pm 0.03^{b}$ & $0.8 \pm 0.09^{\mathrm{b}}$ & $47.6 \pm 5.27^{\mathrm{c}}$ & $3.1 \pm 0.41^{\mathrm{d}}$ & $37.6 \pm 0.18^{\mathrm{b}}$ & 0.34 & 0.35 \\
\hline Guaíba & $3.2 \pm 0.12^{\mathrm{b}}$ & $0.8 \pm 0.09^{b}$ & $41.0 \pm 4.76^{\mathrm{d}}$ & $3.9 \pm 0.61^{\mathrm{b}}$ & $37.0 \pm 1.27^{\mathrm{b}}$ & 0.38 & 0.30 \\
\hline Tamarana & $2.9 \pm 0.24^{b}$ & $0.8 \pm 0.03^{b}$ & $46.7 \pm 3.50^{c}$ & $3.6 \pm 0.46^{c}$ & $38.5 \pm 1.72^{\mathrm{b}}$ & 0.33 & 0.32 \\
\hline
\end{tabular}

${ }^{a}$ Means within each column followed by different lowercase letters are significantly different at the $5 \%$ level by the Tukey test.

dex were also present in the other populations. The tetraploid cytotypes had similar values of TF\%. However, the Zarco index permitted the detection of slight differences among them.

Chromosome variation among populations of the same species has been observed in many plant groups. In the genus Serjania (Nogueira et al., 1995), two populations of $S$. laruotteana, two of $S$. fuscifolia and three of $S$. gracilis with the same chromosome number $(2 n=24)$ had different chromosome rearrangements as observed in $M$. micrantha (Tables II, III; Figures 1-3). Whereas the presence of chromosome races in many groups certainly involves biological adaptation to different habitats, nearly every population of $M$. micrantha studied showed differences in the karyotypes (Tables IV and V). These differences do not seem to be related to adaptive variables, since populations occupying similar environments bear distinct karyotypes. Similarly, karyotype variation was not accompanied by modification in plant morphology. For example, the polyploid cytotype from Apucarana had the largest leaves $(14.0 \mathrm{~cm}$ in length, $7.0 \mathrm{~cm}$ in width) while the polyploid from Salto Apucaraninha had small leaves $(5.0 \mathrm{~cm}$ long and $3.5 \mathrm{~cm}$ in width). The diploid population from Campinas $(2 n=36)$ had leaves $10.0 \mathrm{~cm}$ long and $7.0 \mathrm{~cm}$ in width. These data suggest no correlation between leaf size and ploidy level. Inflorescence types were also constant among all cytotypes, with only small variation in size.

\section{Karyotype evolution}

Chromosome studies have shown that aneuploidy and polyploidy are common in the evolution of Mikania (Ruas and Ruas, 1987; Ruas and Aguiar-Perecin,1997). The basic chromosome number for the genus is represented by a regular aneuploid series with $n=17,18,19,20$, and 21 (Ruas and Aguiar-Perecin,1997). Mikania micrantha contained all chromosome variation found in this genus, exhibiting both aneuploidy and polyploidy (Figures 1-3). In M. micrantha, the cytotypes with $2 n=34,38,40$ (Powell and King, 1969a,b; King et al., 1976; Turner et al., 1979; Strother, 1983; Waisman et al., 1984; Keil et al., 1988) and $2 n=42$, found in this investigation, are probably aneuploid derivatives from $2 n=36$ chromosomes, while the population with $2 n=72$ is a tetraploid which originated by chromosome doubling from an ancestor with $2 n=36$. Cytotypes occur in other species of Mikania. Populations with $2 n=34,36$ and 38 chromosomes were found in $M$. cordifolia (Gaiser, 1954; Powell and King, 1969a,b; Ruas and Ruas, 1987; Robinson et al., 1989), and in $M$. pachyphylla (Nevling, 1969). Polyploidy has also been 


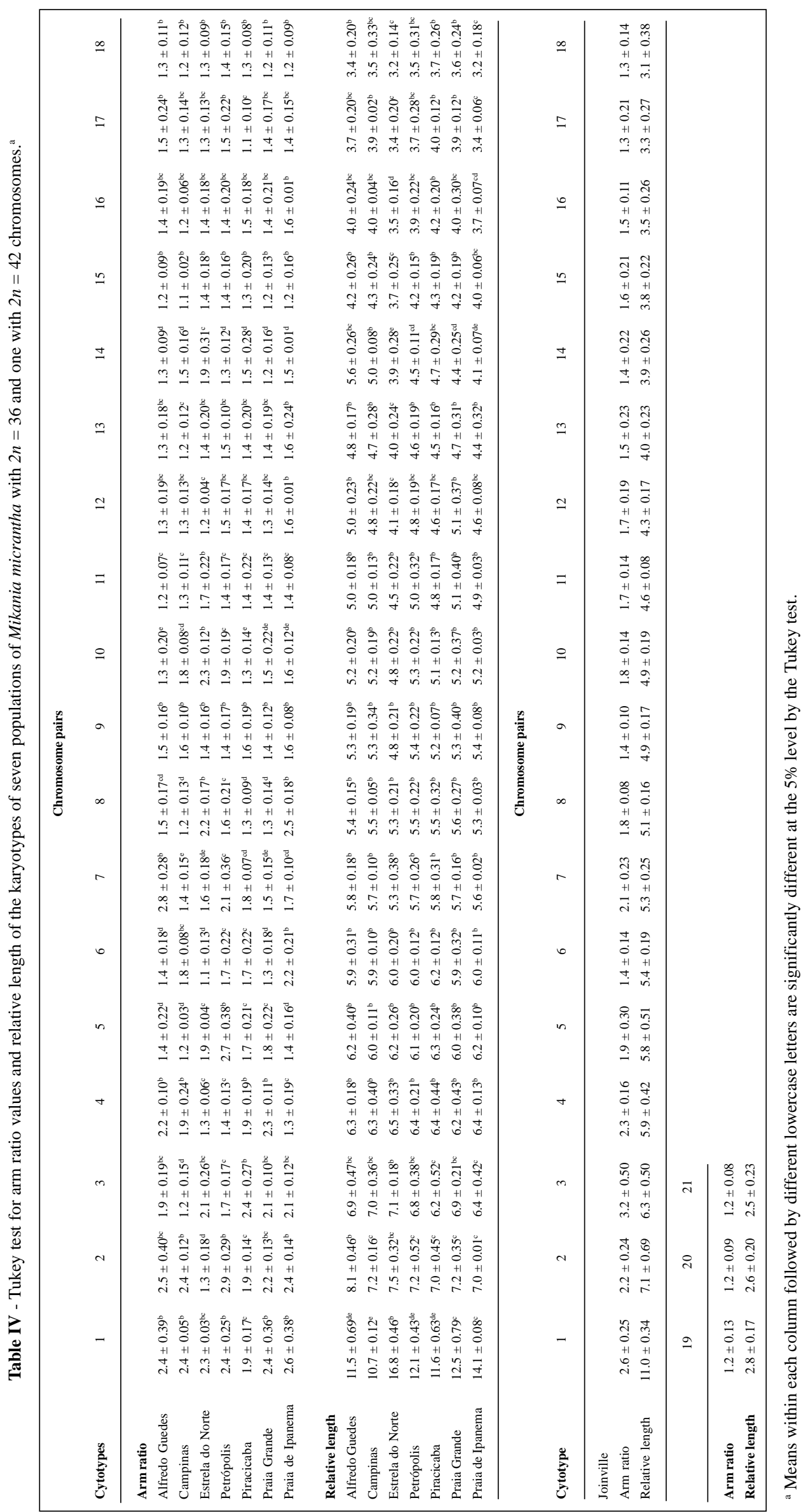




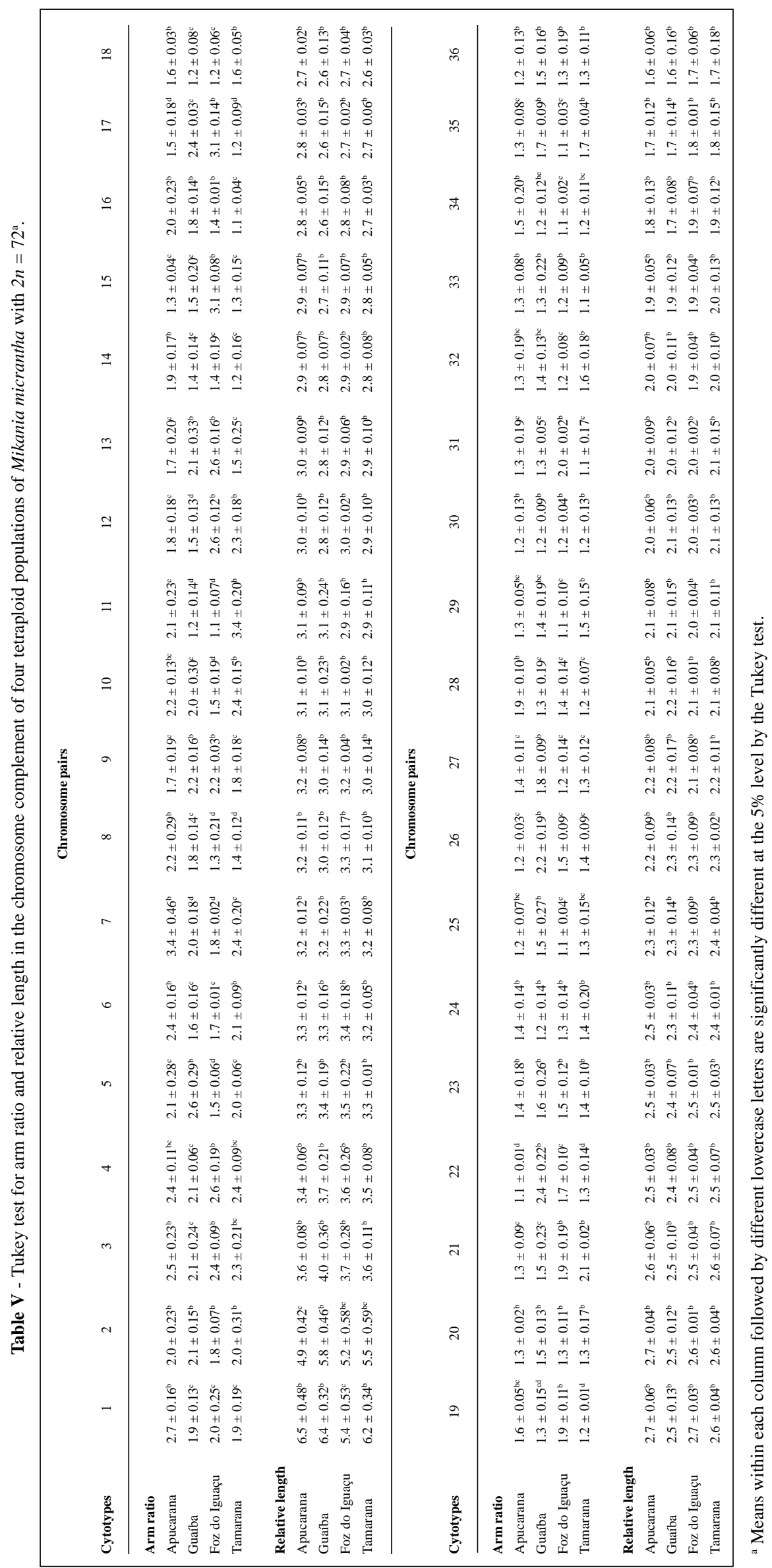


described in other species of Mikania, such as M. viminea $(2 n=4 x=68)$ by Ruas and Ruas (1987) and M. sessilifolia $(2 n=6 x=108)$ by Ruas and Aguiar-Perecin (1997), supporting the view that polyploidy is also a significant mechanism in the chromosome evolution of Mikania.

\section{C-banding analysis}

C-banding was applied to three diploid cytotypes of M. micrantha, including the populations from Piracicaba, Campinas (Figure 5A,B), and Praia Grande (data not shown). $\mathrm{C}$-band analysis revealed a variable pattern in the amount and distribution of heterochromatin in these cytotypes. The cytotype from Piracicaba showed a large heterochromatic block near the secondary constriction of chromosome 1 . Three other chromosome pairs had small centromeric bands (Figure 5A). Similarly, another cytotype (Campinas) exhibited a block of heterochromatin located near the secondary constriction of the large arm of chromosome 1 and several other chromosomes showed centromeric C-bands (Figure 5B). The cytotype from Praia Grande (data not shown) on the other hand had only three pairs of very small centromeric bands and total absence of heterochromatin in chromosome 1. Variation in heterochromatic blocks has been observed in several groups of plants, such as in populations of Trillium kamtaschaticum (Kurabayashi, 1957), Tulbaghia leucantha (Vosa, 1973) and Gibasis karwinskyana (Kenton, 1991). The differences in the patterns of C-band observed among the three cytotypes of $M$. micrantha may be associated with the small detectable variation in the size of the haploid set (Table II). Therefore, at least for the diploid cytotypes, the small differences in the haploid chromosome length may reside in unique and repetitive sequences of DNA.

\section{B-chromosomes}

Mikania micrantha cytotypes display a variable number of small (less than $1 \mu \mathrm{m}$ ) B-chromosomes found in four diploids and two tetraploids of the 12 populations investigated (Figure 6). The populations of Apucarana ( $2 n$ $=72+0-2 \mathrm{Bs})$, Campinas $(2 n=36+3-7 \mathrm{Bs})$, Estrela do Norte (0-1 Bs), Piracicaba $(2 n=36+4-14$ Bs), and Praia Grande $(2 n=36+0-7 \mathrm{Bs})$ showed a variation in number

A

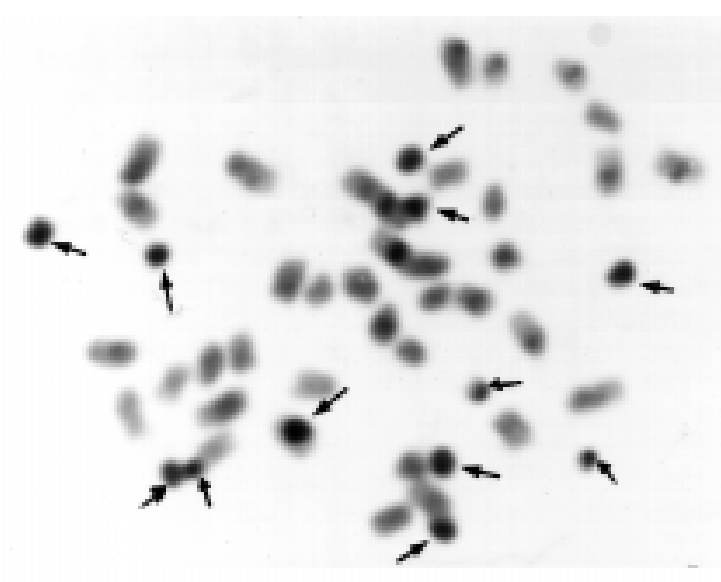

B

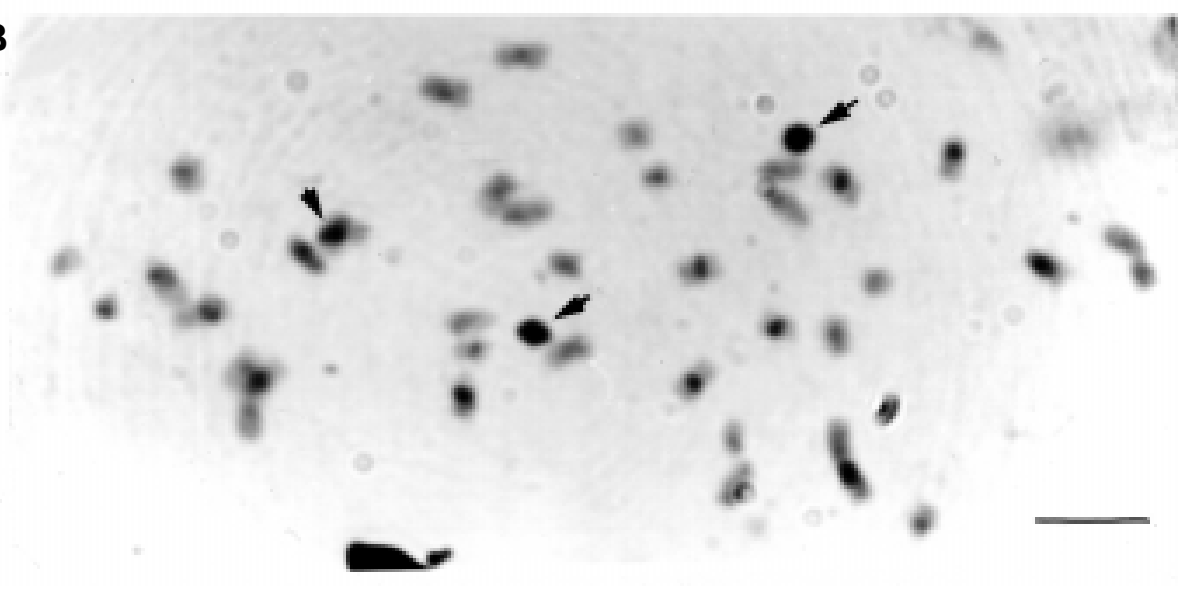

Figure 5 - C-banding pattern of two cytotypes of Mikania micrantha. A. Population from Piracicaba, B. Population from Campinas. Bar $=5 \mu$ m. Arrows indicate some of the heterochromatic B-chromosomes. 
A
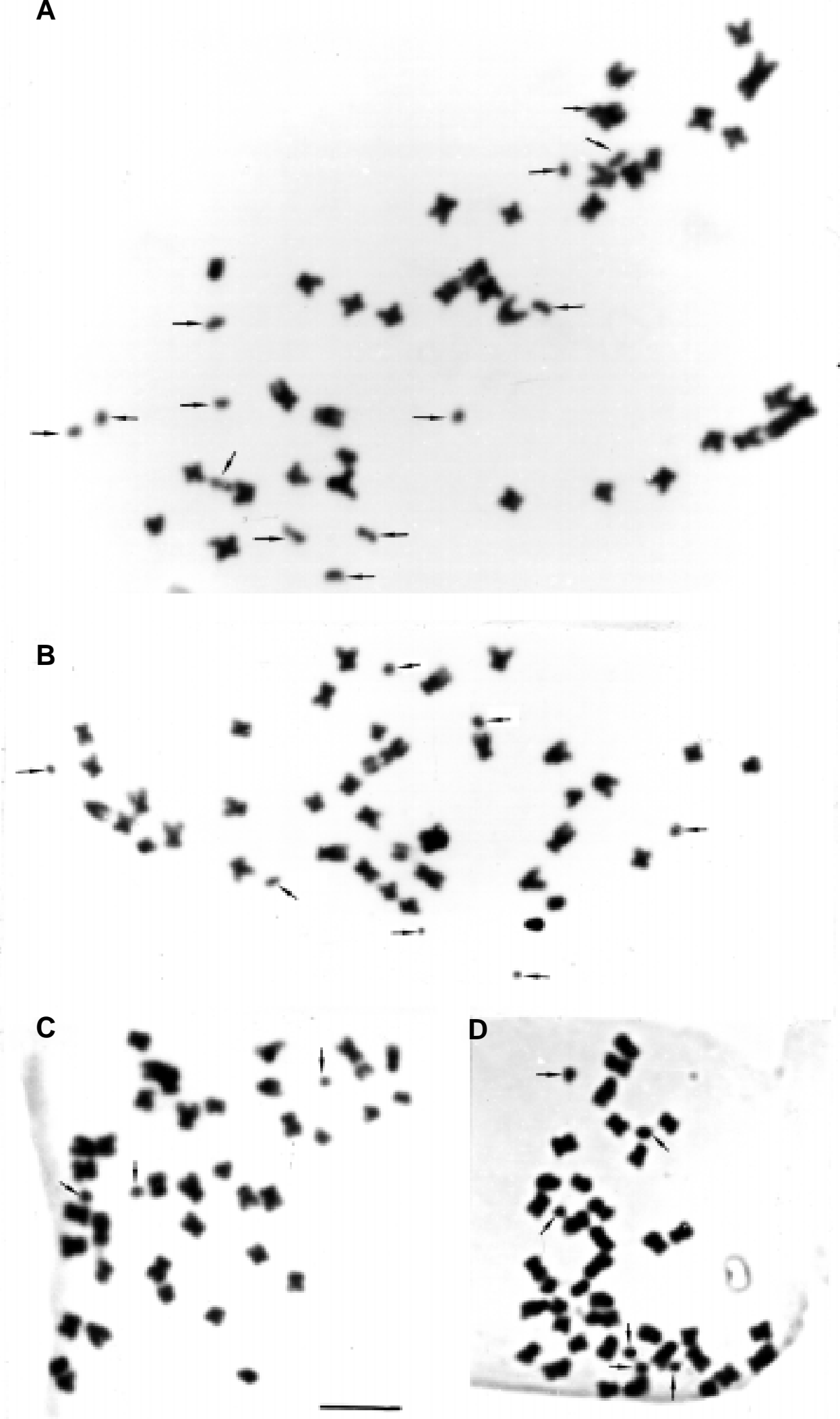

D

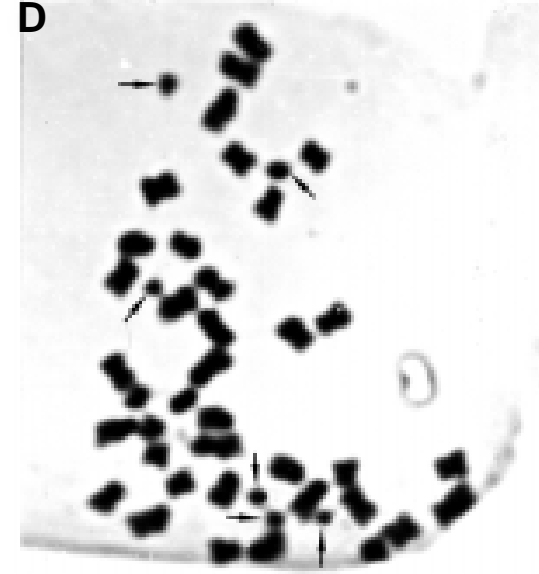

Figure 6 - B-chromosomes (arrows) in mitotic metaphases of three cytotypes of Mikania micrantha. A. Piracicaba, B, C. Praia Grande, D. Campinas. Bar $=5 \mu \mathrm{m}$. 
of Bs among cells of the same root meristem (Table I). This variation may be explained by nondisjunction during mitotic division of the meristem cells. Variable numbers of Bs within individual plants was also seen in Crepis capillaris (Jones, 1995), where the instability of Bs was observed in the cell lineages destined to become the floral organs.

Besides the variation in number from cell to cell and among cytotypes, the B-chromosomes of $M$. micrantha diverged in size (from micro-size to about $0.8 \mu \mathrm{m}$ ) and morphology (Figure 6). According to Jones (1995), at least 65 plant species have two or more forms of B chromosomes. Metacentric (m) and telocentric (t) B chromosomes were observed in Aegilops mutica (Mochizuki, 1960) and large and micro-sized B chromosomes were verified in Brachycome dichromosomatica (Smith-White and Carter, 1970). Loidl (1982) showed that the B chromosomes can be distinguished by their overall size, arm ratio, or Giemsa C-banding in Allium flavum. In M. micrantha, the six cytotypes with Bs show three morphological types, such as m, submetacentric (sm), and subtelocentric (st) types, which also vary from micro-sized in some cells to larger telocentrics in others (Figure 6 A-D). A variable number of very small $\mathrm{m}$ type Bs were found in many cells of the cytotype from Piracicaba. The $m$ type Bs may explain the origin of microBs by centromere misdivision of a single unpaired B, giving rise to two different-sized chromosomes and further derivatives by deletion of parts of the arms. The B-chromosomes of sm type were predominant in the other populations. Jones and Rees (1982) suggested that the variation in the frequency of Bs among populations may be of adaptive value in a stress situation. The distribution of Bs did not follow any specific pattern in the cytotypes of M. micrantha. Their frequency varied among cells of individual plants as well as among populations which occupy different or similar environments such as sea shores (Praia de Ipanema and Praia Grande) and high altitudes (Petrópolis). Therefore, the presence of Bs could not be associated with any adaptive requirement in $M$. micrantha.

C-banding (Figure 5 A,B) in the diploid cytotypes from Piracicaba, Campinas, and Praia Grande (data not shown) showed almost totally heterochromatic B chromosomes. No detectable differences were observed in the Cband pattern between A and B chromosomes, suggesting that homologous repetitive sequences may be present in both A and B chromosomes of M. micrantha.

\section{ACKNOWLEDGMENTS}

This research was supported by Coordenação de Aperfeiçoamento de Pessoal de Nível Superior - CAPES, Ministério da Educação, Brasília, DF, and Universidade Estadual de Londrina, Brazil. Publication supported by FAPESP.

\section{RESUMO}

Mikania micrantha é uma planta herbácea perene, da família Asteraceae, amplamente distribuída através de todo o continente americano. No Brasil, $M$. micrantha tem distribuição irrestrita, ocupando os mais variados ambientes, sem no entanto apresentar variação morfológica. Neste trabalho, usando o método de coloração de Feulgen e bandamento $\mathrm{C}$, foram analisados os cromossomos mitóticos de 12 populações de $M$. micrantha, obtidos de diferentes localidades do Brasil. Citótipos numéricos e estruturais foram identificados, incluindo oito diplóides $(2 n=$ 36 e 42$)$ e quatro tetraplóides $(2 n=72)$. Os números cromossômicos de $2 n=36$ e $2 n=42$ são mostrados pela primeira vez para $M$. micrantha. Todos os cariótipos apresentaram o primeiro par de cromossomos com uma constrição secundária na região mediana do braço maior, seguindo o mesmo padrão observado em todas as espécies de Mikania já estudadas. A análise cromossômica revelou que todos os citótipos variam em algum aspecto. A origem desta variação é atribuída principalmente a ocorrência de inversões e deleção ou adição de fragmentos de DNA. Análise de banda $\mathrm{C}$ em três das 12 populações investigadas revelou polimorfismo na distribuição de heterocromatina. Cromossomos extranumerários, variando em número e morfologia, foram também identificados em seis citótipos de $M$. micrantha. $\mathrm{O}$ bandamento $\mathrm{C}$ mostrou que os cromossomos $\mathrm{Bs}$ apresentaram-se com o mesmo padrão heterocromático dos cromossomos do complemento normal, sugerindo uma possível origem a partir dos cromossomos $\mathrm{A}$.

\section{REFERENCES}

Gaiser, L.O. (1954). Studies in Kuhnünae (Eupatoriae). II. J. Arnold Arbor. Harv. Univ. 35: 87-133.

Huziwara, Y. (1962). Karyotype analysis in some genera of Compositae. VIII. Further studies on the chromosome of Aster. Am. J. Bot. 49: 116-119.

Jones, R.N. (1995). B chromosomes in plants. New Phyt. 131: 411-435.

Jones, R.N. and Rees, H. (1982). B Chromosomes. Academic Press, London.

Keil, D.J., Luckow, M.A. and Pinkava, D.J. (1988). Chromosome studies in Asteraceae from the United States, Mexico, the West Indies, and South America Am. J. Bot. 75: 652-668.

Kenton, A. (1991). Heterochromatin accumulation, disposition, and diversity in Gibasis karwinskyana (Commelinaceae). Chromosoma 100: 468-478.

King, R.M., Kyhos, D.W., Powell, A.M., Reven, P.H. and Robinson, H. (1976). Chromosome numbers in Compositae. XIII. Eupatorieae. Ann. Miss. Bot. Gard. 63: 862-888.

Kurabayashi, M. (1957). Evolution and variation in natural populations of Trillium kamtaschaticum. Jpn. J. Bot. 16: 1-45.

Levan, A., Fredga, A. and Sanderberg, A.A. (1964). Nomenclature for centromeric position in chromosomes. Hereditas 52: 201-220.

Loidl, A.E. (1982). B-chromosomes in Allium flavum (Liliaceae) and some related species. Plant Syst. Evol. 139: 197-207.

Mochizuki, A. (1960). A note on B-chromosomes in natural populations of Aegilops mutica Boiss. in Central Turkey. Wheat Inf. Serv. 11: 31.

Nevling, L.I. (1969). Ecology of an elfin forest in Puerto Rico. 3. Chromosome numbers of some flowering plants. J. Arnold Arbor Harv. Univ. 50: $99-103$.

Nogueira, C.Z., Ruas, P.M., Ruas, C.F. and Ferrucci, M. S. (1995). Karyotypic study of some species of Serjania and Urvillea (Sapindaceae; Tribe Paullinieae). Am. J. Bot. 82: 646-654.

Powell, A.M. and King, R.M. (1969a). Chromosome numbers in the Compositae: Colombian species. Am. J. Bot. 56: 116-121.

Powell, A.M. and King, R.M. (1969b). Chromosome numbers in the Compositae of West Indian species. Sida 3: 319-320.

Robinson, H., Carr, G.D., King, R.M. and Weeden, J.F. (1989). Chromosome numbers in Compositae. XVI: Eupatorieae II. Ann. Miss. Bot. Gard. 76: 1004-1011.

Ruas, C.F. and Aguiar-Perecin, M.L.R. (1997). Chromosome evolution in 
the genus Mikania (Compositae). Am. J. Bot. 84: 1156-1163.

Ruas, P.M. and Ruas, C.F. (1987). Karyotypes and chromosome morphology in the genus Mikania (Compositae). I. Cytologia 52: 551558.

Schwarzacher, T., Ambros, T.P. and Shweizer, D. (1980). Application of Giemsa banding to orchid karyotype analysis. Plant Syst. Evol. 143: 293-297.

Smith-White, S. and Carter, C.R. (1970). The cytology of Brachycome lineariloba. 2. The chromosome species and their relationships. Chromosoma 30: 129-153.

Steel, R.C.D. and Torrie, J.H. (1960). Principles and Procedures of Statistics. McGraw-Hill, New York, NY.

Strother, J.L. (1983). More chromosome studies in Compositae. Am. J. Bot. 70: 1217-1224.
Swamy, A.S. and Ramakrishnan, P.S. (1987). Growth and allocation patterns of Mikania micrantha in successional environments after slash and burn agriculture. Can. J. Bot. 66: 1464-1469.

Turner, B.L., Bacon, J, Urbash, L. and Simpson, B. (1979). Chromosome numbers in South American Compositae. Am. J. Bot. 66: 1973-1978.

Waisman, C.E., Rozemblum, E. and Hunziker, J.H. (1984). Estudios cariológicos en Compositae. I. Darwiniana 25: 217-226.

Vosa, C.G. (1973). Quinacrine fluorescence analysis of chromosome variation in the plant Tulbaghia leucantha. Chromosomes Today 4: 345349.

Zarco, C.R. (1986). A new method for estimating karyotype asymmetry. Taxon 35: 526-530.

(Received July 3, 1998) 